Vol. 3 No. 2 Oktober 2020

\title{
MONETARY POLICY AND TELECOMMUNICATION OUTPUT IN NIGERIA
}

\author{
1 John Abiodun Akinde \\ Adekunle Ajasin University, Nigeria \\ abiodunj26@gmail.com \\ 2 Elijah Oludayo \\ Adekunle Ajasin University, Nigeria \\ adekunleoludayo864@yahoo.com
}

\begin{abstract}
Different policies impact on the growth of the telecommunication sector in Nigeria. One of these policies which influence the expansion or contraction of the telecommunication output is monetary policy. To this end, this research examined the effect of monetary policy on telecommunication output in Nigeria. For the purpose of analysis, time series secondary data were sourced from Central Bank of Nigeria (CBN) statistical bulletin covering the periods1986 to 2018. Autoregressive Distributed Lag (ARDL) technique was employed after examining the stationarity of the data series using Augmented Dickey-Fuller technique. The bound co-integration test revealed that there is long run equilibrium between the monetary policy variables employed and telecommunication output. The ARDL result revealed that money supply had significant and positive effect on telecommunication output in the short and long run; liquidity ratio produced an insignificant and negative relationship with telecommunication output in the short run and insignificant positive effect in the long run; exchange rate had insignificant negative effect in the short run and a significant positive effect on telecommunication output in the long run; consumer price index had significant negative influence on telecommunication outputboth in the short run and long run. The study concluded that monetary policy stimulates telecommunication output in Nigeria. Thus, it was recommended that the monetary authority should pursue an expansionary monetary policy to sustain the positive influence of money supply on telecommunication output in Nigeria while rolling out policy to reduce the liquidity ratio of banks in the short run but increase it in the long run so that the long term favourable effect of liquidity ratio can be felt on telecommunication output.
\end{abstract}

Key words: Monetary policy, telecommunication, co-integration

\section{INTRODUCTION}

The achievement of macroeconomic objectives of price stability, full employment, balance of payment and economic growth has been the focus of government in developed and developing countries. In trying to achieve these objectives, government formulates and implements policies with monetary policy playing leading role. Monetary policy involves the adoption of government monetary instruments to influence the level of economic activities and promote growth. According to Anyanwu and Kalu (2015), it serves as a macroeconomic tool that is used by monetary authority to manage the supply of money through controlling of interest rate and lending to promote economic growth and stability. Obadeyi, Okhiria and Afolabi (2016) opined that monetary policy 
falls within the broad macroeconomic thrusts of managing and controlling the volume, cost and allocation of money and credit in the economy for the purpose of achieving sustainable growth.

The telecommunication industry is a germane sector which has been receiving scholars' attentions in the recent years. According to Roller and Waverman (2001) between 1970 and 1990 telecommunication sector comprised of only fixed line systems and fax. However, recently there is significant development in the telecommunication sector around the globe with mobile phones and other sophisticated gadgets playing leading roles. Telecommunication sector plays germane role in overall development of an economy by linking other sectors together. Adebayo and Akejiuba (2016) opined that telecommunication strategically and generically promote globalization, trade and commerce by providing infrastructure for enhancing communications across countries. Shakeel, Khan and Malik (2012) stated that the growth of telecommunication sector plays important role in reducing operating cost of business, cutting of inefficiency in the transmission of business information and expanding of market for goods and services through the linkage of different sectors in the economy. Thus, leading nations like Germany, United State of America, United Kingdom, China, India, Japan, Korea and Switzerland among others have been placing priorities in developing and expanding their telecommunication sector. Nigeria and other developing countries should not be excluded in this pursuit.

The relationship between monetary policy and performance of the economy has been theoretically and empirically discussed in literature (Udede2014; Micheal \& Ebibai, 2014; Ajibola, 2016; Obadeyiet al., 2016). Keynes (1936) theoretically opined that monetary policy plays important roles in stimulating economic activities through increase money supply which enhances real sector growth and employment. Also, McKinnon (1973); Shaw (1973); Matheson (1980) and Levine (1997) agreed with this assertion that growth rate of economic growth and development in the economy is determined by stock of money available in the economy. However, Robinson (1952) and Fry (1997) theoretically stated other factors other than money supply may play significant role in the growth of an economy, depending on the nature that the economy.

Over the years, the objectives of Central Bank of Nigeria are the stimulation of output and employment and the promotion of domestic and external stability through the formulation of effective and efficient monetary policy. In line with the general philosophy of economic management under Structural Adjustment Programme (SAP) which was adopted in 1986 in Nigeria, monetary policy has been channeled towards encouraging investment in different sectors of the economy and controlling inflation hence achieving economic growth.

The potency of monetary policy in stimulating economic activities and growth in Nigeria has been a subject of discussion among scholars and experts. Ajibola (2016) opined that monetary policy seems not to have achieved the desired objectives of employment and fast growth rate inspite of the policy thrust of monetary authority. Obadeyi, et al., (2016) argued that monetary policy in Nigeria failed to influence growth appropriately due to underdevelopment of the financial system through which monetary instruments influenced growth. The reasons why monetary policy continues to encounter difficulty in bringing the desired dividend may not be unconnected with the persistent problems of rising unemployment, low investment, divestment, poor market demand and double digit inflation rate which have plagued Nigeria economy.

The Nigerian telecommunication sector, though still emerging, plays important role in the economy through its ability to connect different sectors of the economy together. The ease with which business and other economic activities are now been conducted remained a focal merit of telecommunication development in Nigeria.However, it appears enough attention has not been given to this sector when compared with other sectors like agricultural sector, manufacturing 
sector, oil and gas sector, and mining sectorforgetting that the telecommunication sector also had its fair share of contribution to the Nigeria gross domestic product over the years. For instance, telecommunication output rose from $\$ 29.40$ billion in year 2000 to $\$ 339.92$ billion in 2001 and \#422.73 billion in 2002 accounting for $1.32 \%$ and $1.45 \%$ of real GDP respectively. As at 2012, the contribution of telecommunication sector to total real GDP has risen to 8.63\%. Between 2017 and 2018, the contribution of telecommunication sector to total real GDP rose from $8.65 \%$ to $9.45 \%$ respectively accounting for about $8.47 \%$ increase $(\mathrm{CBN}, 2018)$.

Given the increasing role of telecommunication industry in the economic growth of developed countries, there is need to focus more on the sector in developing countries like Nigeria. Also, recognizing the essential impact of monetary policy on economic subsectors (telecommunication inclusive) in Nigeria, the pertinent question is: what is the effect of monetary policy on telecommunication output in Nigeria? Though studies have been conducted on the efficacy of monetary policy in Nigeria, majority of these studies focused on the effect of monetary policy on economic growth (Chuku, 2009; Udede, 2014; Anyanwu \& Kalu, 2015; Obadeyi, et al., 2016; Ajibola, 2016). Also, some studies have considered the effect of telecommunication industry on economic growth in Nigeria (David, 2013; Wilson, David, Beatrice \& Mary, 2014; Adebayo \& Ekejiuba, 2016). However, from the reviewed studies, it is revealing that there is a vacuum that needed to be filled as regard the effect of monetary policy on telecommunication output in Nigeria. So, this formed the thrust of this study. Therefore, this study investigates the effect of monetary policy on telecommunication output in Nigeria. Furthermore, exchange rate and liquidity ratio were employed as important variables through which monetary policy influences telecommunication output in Nigeria.

\section{REVIEW OF LITERATURE}

Monetary policy as price stabilization and economic growth tool plays important role in stimulating economic activities in the economy which are germane for reducing unemployment and enhancing standard of living. However, the actualization of higher economic growth relies upon the effect of monetary policy on sectoral performance in the economy(Zhang \& Sun, 2017).The monetary authority adopts instruments like open market operations, lending rate, cash reserve ratio, special directives and intermediate instruments like exchange rate and short term interest rate to influence money in circulation and lending activities of commercial banks (Srithilat $\&$ Sun, 2017). Monetary policy which can either be expansionary or contractionary plays important roles in the development of an economy.

Telecommunication is the application of technology that allowed people to communicate at a distance by voice, text, graphics and videos (Wilson, et al., 2014). The broad spectrum includes telephony and video conferencing, broadcast and interactive television, instant messaging, e-mail, distributed collaboration, a host of Web-and Internet-based communication, and data transmission (Shakeel, et al., 2012). Telecommunication plays important role in the society through the intermediation and dissemination of information. The telecommunication sector provides job opportunities, attract both local and international investment and contribute to national security in the economy.

Theoretically, there are many theories that explain the role and working of monetary policy in the economy. However, the Neo-classical theory which was developed by Friedman (1968) is the major theory that this study rest upon. The theory stressed the role of monetary policy in influencing the volume, cost and direction of money supply in the economy. Friedman (1968) asserted that "inflation is a monetary phenomenon which is presents everywhere and monetary 
authority can reduce unemployment and enhance economic activities by increasing money supply in the short run with caution. The theory stated that monetary policy plays important role in influencing wellbeing and money supply must grow at a steady rate in order to enhance economic growth (Essian, 2005). It thus expected that changes in money supply through the adoption of monetary policy tools will influence the level of spending and investment in the economy.

As a result of the theoretical role of monetary policy in the economy, different studies have been empirical conducted to investigate the effect of monetary policy on economic growth. Chukwu (2009) analyzed the effect of monetary policy innovations on economic growth in Nigeria using Structural Vector Auto-Regression (SVAR). Evidence of positive relationship was established between monetary policy innovations and economic growth. Amassomaet al (2011) studied the effect of monetary policy on macroeconomic variables in Nigeria for the period 1986 to 2009 using ordinary least squared technique. It was revealed that monetary policy had a significant effect on exchange rate and money supply while monetary policy was observed to have an insignificant influence on price instability. Akujobi (2012) looked at the relationship between monetary policy instrument and economic development of Nigeria analyzed through OLS technique. It was reported that treasury bill, minimum rediscount rate and liquidity rate had significant impact on economic development in Nigeria.

Onyeiwu (2012) adopted ordinary least squares to investigate the impact of monetary policy on the Nigerian economy between 1981 and 2008. It was found that monetary policy represented by money supply exerted a positive impact on GDP growth and Balance of Payment but negative impact on rate of inflation. Micheal and Ebibai (2014) studied the impact of monetary policy on gross domestic product in Nigeria. The result of the OLS showed that monetary policy had positive and significant effect on economic growth. Udede (2014) examined the impact of monetary policy on the growth of Nigeria economy from 1981 to 2012 by establishing the effect of money supply, interest rate, exchange rate and liquidity ratio on economic growth of the country within the period considered analyzed with Augmented Dickey Fuller Unit Root Test, Johansen Co-integration Test and Vector Error Correction Mechanism (VECM). It was indicated that only money supply, interest rate and exchange rate had positive effect on economic growth while liquidity ratio had negative effect on economic growth in Nigeria.

In Pakistan, Chughtai, Malik and Malik (2015) explored the impact of economic variables including inflation rate, interest rate and exchange rate on economic growth based on secondary datafrom 1981 to 2013. Analysis was conducted using OLS and it was revealed that both inflation rate and interest rate negatively influence Pakistan's economic growth while exchange rate was found to positively impact economic growth. Obadeyi et al., (2016) assessed the impact of monetary policy on the growth of emerging economy covering the period of 1990 and 2012 analyzed with ordinary least square. It was revealed that monetary policy through money supply and monetary policy rate had positive and insignificant effect on economic growth in Nigeria. Similarly, Ajibola (2016) conducted a study on the effectiveness of monetary policy on economic growth in Nigeria using annual time series data from 1981 to 2014 analyzed with the aid of OLS. It was reported that narrow money supply, broad money supply, lending rate and gross capital formation had positive effect on economic growth while inflation had negative effect oneconomic growth.

Regarding the role of telecommunication in the economy, Shakeel, et al., (2012) investigated the relationship betweentelecommunications and development in Pakistan. The study employed primary data collected through questionnaire; analyzed with simple regression technique and it was found that telecommunication had positive and significant effect on economic 
growth.David (2013) examined the impact of real investment in telecommunication on economic growth in Nigeria time series data from 1980 to 2010 analyzed with least squares and fully modified ordinary least squares techniques. Findings showed that labour employed, capital stock, real investment in telecommunication and electricity supply had significant effect on economic growth in the short run equilibrium in Nigeria.

Wilson, et al (2014) conducted a study on the implication of telecommunication development on economic growth in five leading ICT developed countries in African. The study employed OLS and Granger causality techniques to examine the effect of number of fixed-lines and mobile phone subscribers per 100 persons on gross domestic product at current prices. The result of the granger causality test showed no causal relationship between mobile and fixed teledensity and economic growth while OLS results revealed that telecommunication development had positive and significant effect on economic growth in Africa. Adebayo and Ekejiuba (2016) employed descriptive techniques to assess the contribution of telecommunication to economic growth in Nigeria using data from established regulatory bodies on growth rate of subscribers of telecommunications, numbers of employees in the sector and gross domestic product. It was discovered that telecommunication sector positively influenced economic growth of Nigeria. Matalqah and Warad (2017) evaluated the impact of infrastructure telecommunications investment on economic growth in the Arab countries, using advanced fully modified ordinary least squares and panel data analysis techniques to analyze data of 12 countries from 1996 to 2015. The evidence of positive relationship was reported between investment in infrastructure of telecommunications sector and economic growth in non-oil producing countries in the long-term while investment in telecommunication had insignificant impact on the economic growth of oil-producing countries.

From the reviewed literature, it was found that majority of studies conducted largely focus on the effect of monetary policy on overall economic growth. Also, some studies like Shakeel, et al., (2012); David (2013); Wilson, et al., (2014); Adebayo and Ekejiuba (2016); Matalqah and Warad (2017) mainly focus on the effect of telecommunication industry on economic growth.Little or no attention was given to investigate the effect of monetary policy on telecommunication sector which created a gap to be explored. The telecommunication industry is germane to the development of an economy in the modern society. Recently, attentions have been placed on the telecommunication being a sector that leads an industrial evolution through its capacity to connect people around the world for trade, business and investment purposes.

\section{RESEARCH METHODOLOGY}

This paper adopted non experimental research design which is quantitative in nature to examine the effect of monetary policy on telecommunication output in Nigeria. This is because the study dealt with the establishment of the relationship between the explanatory variables and dependent variable using non controllable secondary data. This study adopted annual time series data set covering the period 1986 to 2018. Data for the study were obtained from Central Bank of Nigeria (CBN) Statistical Bulletin (2018).

\section{Data Estimation Techniques}

To avoid the problem of spurious regression, the stationarity of the data set employed in estimation of the equation were ascertained.The Augmented-Dickey Fullerunit root test was employed to test the stationarity level of the series to determine the order of integration of the variables. To assess the existence of long-run equilibrium relationship among the variables, bound 
co-integration technique was employed.The study adopted Autoregressive Distributed Lag (ARDL)techniqueto examine the effect of money supply, exchange rate, and liquidity ratio on telecommunication sector output base on the result of the unit root test.

Autoregressive Distributed Lag technique is a co-integration method which estimates the long run and short run parameters of regression equation simultaneously. Autoregressive Distributed Lag co-integration approach has certain econometric advantages over other cointegration methods in that it helps avoid endogeneity problems. In this method, pre-testing for unit roots may not necessary because it is appropriate whether the variables are $\mathrm{I}(0)$, I(1) or mutually integrated.

\section{Model Specification}

The model for this research was built on Neo-Classical Theory of Milton Friedman. The theory emphasizes the role of monetary policy in controlling the cost of money to influence economic activities and the growth of real sector in the economy. The study adapted the empirical model of Srithilat and Sun (2017) wherein gross domestic product was modeled as a function of money supply, real exchange rate, interest rate and inflation. The selected variables were in line with previous empirical studies. By modification, the model for this study is given as:

TELOUT $=f(\mathrm{MS}, \mathrm{EXR}, \mathrm{LR}, \mathrm{CPI})$

This is econometrically given is long run form as:

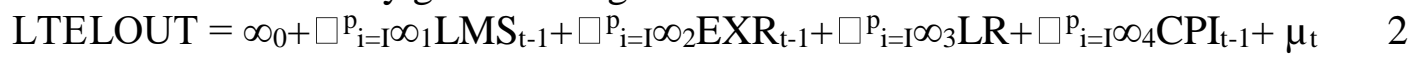

However, the short run error correction form of the ARDL equation is given as:

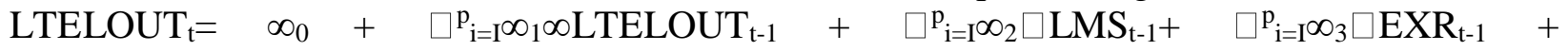

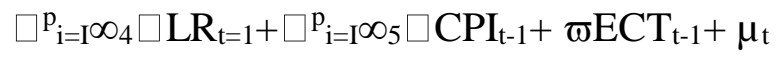
3

Where:

TELOUT $=$ Telecommunication Output. This measures performance of telecommunication industry in terms of contribution to gross domestic product.

MS = Money Supply. This measures the volume of money in circulation which was captured with broad money supply.

$\mathrm{EXR}=$ Exchange Rate. This is the exchange rate of naira to dollar.

$\mathrm{LR}=$ Liquidity Ratio. It is the liquidity ratio of banks

$\mathrm{CPI}=$ Consumer Price Index.

$\infty_{0}=$ Constant Term

$\infty_{1}-\infty_{4}=$ Coefficient of the parameters.

$\mathrm{U}=$ Error Term

$\varpi \square \square \square$ Speed of Adjustment in the short run dynamic equation

$\mathrm{ECM}=$ Error Correction Model

\section{RESULT AND DISCUSSION}

The nature of the data employed required the adoption of econometric techniques which are robust for adequate findings. In this section, results of unit root test, bound co-integration test, serial correlation test and Autoregressive Distributed Lag were presented.

Stationarity Test 
The stationarity of the variables in this study was examined by conducting the unit root test. Augmented Dickey-Fuller (ADF) unit root test was used. The results of the ADF statistics are presented in table 1 thus:

Table 1: Result of ADF unit root test

\begin{tabular}{|c|c|c|c|c|c|c|}
\hline \multirow[t]{2}{*}{ Variables } & \multicolumn{2}{|c|}{ ADF statistics } & \multicolumn{2}{|c|}{ Critical values } & \multirow[t]{2}{*}{$\begin{array}{ll}\text { Order } & \text { of } \\
\text { integration } & \end{array}$} & \multirow[t]{2}{*}{ Remark } \\
\hline & At level & $1^{\text {st }}$ diff & $5 \%$ & $10 \%$ & & \\
\hline LTELOUT & -0.289531 & -5.098752 & -2.960411 & -2.619160 & $\mathrm{I}(1)$ & $\mathrm{S}$ \\
\hline LMS & -2.490854 & -3.579066 & -2.960411 & -2.619160 & $\mathrm{I}(1)$ & $\mathrm{S}$ \\
\hline LR & -2.916700 & -6.026940 & -2.960411 & -2.619160 & $\mathrm{I}(1)$ & $\mathrm{S}$ \\
\hline EXR & 1.316609 & -3.986330 & -2.960411 & -2.619160 & $\mathrm{I}(1)$ & $\mathrm{S}$ \\
\hline LCPI & -1.162590 & -3.362329 & -2.963972 & -2.621007 & $\mathrm{I}(1)$ & $\mathrm{S}$ \\
\hline
\end{tabular}

Source: Authors'Computation, 2020

The condition for the stationarity of the data series is that the ADF statistics must be greater than the critical values in absolute term at 5\% significant level. From the result, it was discovered that all the variables have unit root problem. To solve the unit root problem, the variables were differenced. The results revealed that all the variables were stationary at first difference. This means that the variables were integrated of order one I(1). This implies that there is short run equilibrium relationship among the variables.

\section{Co-integration Test}

The co-integration test in this study was conducted to examine the long run equilibrium among the variables. ARDL bound co-integration was used in this study. The result is presented in table 2 below:

Table 2: Result of ARDL Bound Tests

Null Hypothesis: No long-run relationships exist

\begin{tabular}{|l|c|c|}
\hline Test Statistic & Value & K \\
\hline F-statistic & 5.396760 & 4 \\
\hline Critical Value Bounds \\
\hline Significance & I0 Bound & I1 Bound \\
\hline $10 \%$ & 2.45 & 3.52 \\
\hline $5 \%$ & 2.86 & 4.01 \\
\hline $2.5 \%$ & 3.25 & 4.49 \\
\hline $1 \%$ & 3.74 & 5.06 \\
\hline
\end{tabular}

\section{Source: Authors' Computation, 2020}

The condition for co-integration of the variables is that the F-statistic must be greater than the critical value at 5 percent level of significance at both lower and upper bounds. Given this, the result revealed that the variables were co-integrated at 5 percent significance level. This is as shown by the F-statistic value of 5.396760 which is greater than 2.86 and 4.01 at lower bound and upper bound respectively. This means that there is significant long run equilibrium relationship among the variables. The implication of this is that the variables will not wander apart in the long 
run and as such monetary policy large influence and explain the monument of telecommunication output the long run.

\section{Serial Correlation Test}

This test was conducted to examine the presence or absence of serial correlation among the residual of the variables. Breusch-Godfrey serial correlation test technique was adopted in this study. The result is presented table 3 below:

\section{Table 3: Result of Breusch-Godfrey Serial Correlation LM Test}

\begin{tabular}{|l|r|l|r|}
\hline F-statistic & 0.994107 & Prob. F(2,19) & 0.3885 \\
\hline Obs*R-squared & 2.936631 & Prob. Chi-Square(2) & 0.2303 \\
\hline
\end{tabular}

\section{Source: Authors' Computation, 2020}

The null hypothesis tested is that there is no serial correlation in the series. The decision criterion is to accept the null hypothesis if the P-value of the F-statistic is greater than 0.05 and to accept the alternate hypothesis if otherwise. From Table 3, the result showed that the p-value (0.3885) is greater than 0.05, therefore, the null hypothesis cannot be rejected. This implies that the null hypothesis is true. That is, there is no problem of serial correlation in the series.

\section{Interpretation and implications of result}

The result of the autoregressive distributed lag estimation is presented in table 4 to explain the influence of the explanatory variables on the explained variable.

Table 4: Result of ARDL

Dependent Variable: LTELOUT

\begin{tabular}{|c|r|r|r|r|}
\hline \multicolumn{5}{|c|}{ Short Run Estimates } \\
\hline Variable & Coefficient & Std. Error & t-Statistic & Prob. ${ }^{*}$ \\
\hline LMS & 1.064481 & 0.300782 & 3.539039 & 0.0019 \\
\hline LR & -0.005410 & 0.008136 & -0.664953 & 0.5133 \\
\hline LR(-1) & 0.003731 & 0.008611 & 0.433249 & 0.6693 \\
\hline EXR & -0.001442 & 0.003230 & -0.446387 & 0.6599 \\
\hline EXR(-1) & -0.005333 & 0.005221 & -1.021329 & 0.3187 \\
\hline LCPI & -0.867173 & 0.288667 & -3.004062 & 0.0068 \\
\hline CointEq(-1) & -0.662419 & 0.135942 & -4.872805 & 0.0001 \\
\hline \multicolumn{5}{|r|}{ Long Run Estimates } \\
\hline LMS & 1.606960 & 0.292575 & 5.492472 & 0.0000 \\
\hline LR & 0.018221 & 0.017906 & 1.017562 & 0.3205 \\
\hline EXR & 0.014078 & 0.004011 & 3.509552 & 0.0021 \\
\hline LCPI & -1.309100 & 0.322272 & -4.062096 & 0.0006 \\
\hline C & -3.207558 & 1.372889 & -2.336356 & 0.0295 \\
\hline R-squared & \multicolumn{5}{|c|}{0.989639} \\
Adjusted R-squared \\
F-statistic \\
Prob(F-statistic)
\end{tabular}

Source: Authors' Computation, 2020 
The result, as presented in table 4, reveals that money supply had significant and positive relationship with telecommunication output in the short run. This agrees with the theoretical expectation that broad money supply should enhance telecommunication output. The coefficient 1.064481 and p-value 0.0019 indicated that a percentage change in broad money supply will lead to significant increase in telecommunication output in the short run to the tune of 106 percent in Nigeria. Also, in the long run, money supply maintains a significant positive influence on telecommunication output as shown by the coefficient of 1.606960 and p-value of 0.0000 . This shows that a percentage change in money supply will cause about 160 percent significant improvement in telecommunication output in the long run in Nigeria.

Also, it is discovered from the result that liquidity ratio had insignificant and negative relationship with the dependent variable in the current period and an insignificant positive association at lag one as shown by their respective coefficients and p-values. In the long run, liquidity ratio produced an insignificant positive effect on the dependent variable. The coefficient 0.018221 indicated that a percentage change in liquidity ratio of banks will cause a positive change in telecommunication output to the tune of 1.8 percent. This implies that the ability of deposit money banks to meet short term liquidity demand of telecommunication companies will be favourable to telecommunication output in the long run.

Furthermore, the result revealed that exchange rate demonstrated insignificant and negative influence on telecommunication output in the short run given the coefficients -0.001442 and 0.005333 in the current period and at lag one respectively. This indicated that the present depreciation in the value of naira is a hindrance to improvement in telecommunication output in Nigeria. Contrarily, exchange rate exhibited a significant positive influence on the dependent variable in the long run given the coefficient 0.014078 and $p$-value 0.0021 . This is an indication that a favourable change in the value of naira relative to dollar will produce a significant improvement in telecommunication output to the tune of 1.4 percent in the long run.

The result also revealed that consumer price index exhibited a significant and negative relationship with the dependent variable both in the short run and long run. The short run coefficient is -0.867173 with p-value 0.0068 and the long run coefficient is -1.309100 with p-value 0.0006 respectively. This implies that increase in consumer price index in Nigeria will lead to about 86.7 percent decline in telecommunication output in the short run and about 130 percent decrease in the long run. This is an indication that high inflation rate is an obstacle to improved performance of telecommunication firms in Nigeria. This explains the low contribution of telecommunication sector to gross domestic product in Nigeria.

The error correction factor of the ARDL result was correctly signed. The error correction coefficient -0.662419 and p-value 0.0001 indicated that any short run disequilibrium among the variables will be adjusted at a significant speed of 66.2 percent in the long run. This explains that the ability of monetary policy indicators to converge in explaining variation in telecommunication output in the long run is significant.

The coefficient of determination $\left(\mathrm{R}^{2}\right)$ measured the goodness of fit of the regression line. The $\mathrm{R}^{2} 0.9896$ indicated that the goodness of fit is highly good. This implies that 98.96 percent of the total variation in telecommunication output in Nigeria within the period of study was explained by money supply, liquidity ratio, exchange rate and consumer price index. The remaining 1.04 percent is explained by other variables not included in this study but were captured by the error term $(\mu)$. The overall significance of the model was tested using the F-statistic. The p-value 0.000000 of the F-statistic showed that the model is statistically significant in explaining the variation in telecommunication growth in Nigeria. Therefore, the null hypothesis that monetary 
policy does not have significant effect on telecommunication output in Nigeria was rejected. This means that the alternative hypothesis was accepted which implies that monetary policy had significant effect on telecommunication output in Nigeria.

1. Conclusion and Recommendations

The potency of monetary policy in stimulating economic activities and sectoral performance cannot be underestimated. From the foregoing, this study investigated the effect of monetary policy on telecommunication output in Nigeria. Arising from the analysis, it was found that, money supply enhanced telecommunication output both in the short and long run; liquidity ratio negatively influenced telecommunication output in the short run but producedpositive effect in the long run. Also, exchange rate impede telecommunication output in the short run but contributed positively to telecommunication in the long run and finally, consumer price index had negative influence on telecommunication output. These findings conformed to the empirical discoveries of Udede (2014); Micheal and Ebibai (2014); Ajibola (2016); Obadeyiet al., (2016). It was concluded that monetary policy enhanced telecommunication output both in the short and long run.

Thus, monetary authority should pursue an expansionary monetary policy to sustain the positive influence of money supply on telecommunication output in Nigeria.The central bank should roll out policy to reduce the liquidity ratio of banks in the short run but increase it in the long run so that the long term favourable effect of liquidity ratio can be felt on telecommunication output.Nigeria government should pursue a managed exchange rate system to regulate the persistent fluctuation in the price of naira relative to dollar so that further depreciation of the naira can be guide against. Finally, Nigeria government while increasing money supply can as well increase indirect tax to check inflationary pressure that may result from money supply.

\section{References}

Adebayo, A.A. \&Akejiuba, C.O. (2016).A review of the contributions of telecommunications to the economic growth of Nigeria.International Journal of Electrical \& Electronics Engineering, 3(2), $10-13$.

Ajibola, J.O. (2016). Effective monetary policy as a recipe for macroeconomic stability in Nigeria.Developing Country Studies, 6(4), 38 - 48.

Akujobi, L.E. (2012). Monetary policy and Nigeria's economic development.African Research Review, 4(4), 153-161.

Amassoma, D., Nwosa, P.I \&Olaiya, S.A. (2011). An appraisal of monetary policy and its effect on macroeconomic stabilization in Nigeria.Journal of Emerging Trends in Economics and Management Sciences, 2(3),232-237.

Chughtai, M.W., Malik, M.W. \& Malik, R. (2015).Impact of major economic variables on economic growth of Pakistan.ActaUniversitatisDanubius, 11(2), 94 - 106.

Chuku, C.A. (2009). Measuring the effects of monetary policy innovations in Nigeria: A structural vector autoregressive approach.African Journal of Accounting, Economics, Finance and Banking Research, 5(5), 112 - 129. 
David, O.O. (2013). The effect of investment in telecommunication on economic growth: Evidence from Nigeria. International Journal of Advancements in Research \& Technology, $2(1), 1-23$.

Essian, U. (2005).Macro economic theory.Calabar: Sae Sprint (Nig). Co

Friedman, M. (1968).The role of monetary policy. The optimum quantity of money, ed. Milton Friedman. Chicago: Aldine.

Fry, M. (1997). In favor of financial liberalization.Economic, 107, 754-770.

Keynes, J.M. (1936). The general theory of employment, interest and money. London, UK: Palgrave Macmillan.

Levine, R. (1997). Financial development and growth: Views and agenda. Journal of Economic Literature, 35, 688-726.

Matalqah, M.M. \&Warad, T.M. (2017). The impact of telecom infrastructure on the economic growth: The case of oil-producing and non-oil producing Arab Countries. International Journal of Economics and Financial Issues, 7(3), 423-428.

Matheson, D. (1980). Financial reforms and Stabilization Policy in Developed Economies.Development Economics, 7(3), 359-395.

Mckinnon, R. (1973). Money and capital in economic development. Washington DC: The Brooking Institution.

Micheal, B. \&Ebibai, T.S. (2014).Monetary policy and economic growth in Nigeria (19802011).Asia Economic and Financial Review, 4(1), 20-32.

Obadeyi, J.A., Okhiria, A.O. \&Afolabi, V.K. (2016).Evaluating the impact of monetary policy on the growth of emerging Economy: Nigerian experience.American Journal of Economics, 6(5), 241-249

Robinson, J. (1956). The accumulation of capital.Illinios: Richard D. Irwin.

Roller, L.H. \&Waverman, L. (2001). Telecommunications infrastructure and economic development: A simultaneous approach. American Economic Review, 91(4), 909-923.

Shakeel, M., Khan, R.AG.\& Malik, H.R. (2012). The impact of monetary policy on economic development: Evidence from Lao PDR. Global Journal of Human-Social Science, 17(2), $8-16$.

Shaw, E. (1973). Financial deepening in economic development.New York: Oxford University Press. 
Srithilat, K. \& Sun, G. (2017). The Impact of Monetary Policy on Economic Development: Evidence from Lao PDR. Global Journal of HUMAN-SOCIAL SCIENCE: E-Economics, $17(2), 9-16$

Udede, C.C. (2014). Monetary policy and economic growth of Nigeria (1981-2012).Journal of Policy and Development Studies, 9 (1), 234-247.

Wilson, A., David, U., Beatrice, E. \& Mary, O. (2014).How telecommunication development aids economic growth: Evidence from ITU ICT development index top five countries for African region. International Journal of Business, Economics and Management, 1(2), 1628

Zhang, C., \& Sun, Y. (2017).Confidence in Chinese monetary policy.International Review of Econo-mics\& Finance.https://doi.org/10.1016/j.iref. 2017.01.009 